\title{
FINANCIAL RISK AND REAL VARIABLES: EVIDENCE BASED ON A SVAR ANALYSIS OF THE CZECH ECONOMY
}

\section{Vít Pošta, Zdeněk Pikhart}

\begin{abstract}
:
Recent financial crisis has brought to attention the issues of interactions between financial markets and real economy. This paper presents an analysis of the possible explicit effects of various measures of financial markets' risk on real economy based on impulse - response functions within structural vector autoregressive models. As discussed in the paper the riskiness of financial markets is closely related to the more traditional mechanisms based on financial accelerator approach, however, although the issue of financial risk is closely tied with the financial accelerator model, broader effects outside this model may be considered as well. The analysis is carried out for the Czech Republic. The estimates of the responses in the impulse-response analyses typically correspond with the hypothesized effects of the financial risk factors on the real variables; also the interrelations between some of the financial risk factors are obvious. We conclude that increased financial risk seems to be an amplifying element rather than the key driver in the interactions between financial and real economy.
\end{abstract}

Keywords: business fluctuations, Czech economy, financial crisis, financial accelerator, financial markets' risk, SVAR.

JEL Classification: E32, E44, G01

\section{Introduction}

The interrelations between risk and the behaviour of real economies is not novel in economic theory, however, the recent economic and financial crises have turned the spotlight on these and related issues. Typically, the attention is centred on the key mechanisms, which might be subsumed under the financial accelerator theory; introduced further below. As it will be shown, risk perception by the economic agents is an integral part of this mechanism although the effects of risk on real activity may be considered in much broader terms.

Structurally restricted vector autoregressive models will be used in the paper to estimate the impacts of shocks to financial risk factors on the real variables. The purpose of the analysis is to directly focus on the role of explicit measures of risk in the behaviour of a real economy as these factors are usually considered implicitly as part of other tested mechanisms. The analysis will be performed for the Czech economy only and there are two reasons for this: first, we were able to obtain all the data we needed for this economy

* Vít Pošta, Ministry of Finance, Department of Microeconomics, University of Economics, Prague (vit.posta@vse.cz);

Zdeněk Pikhart, Ministry of Finance, Department of Economic and Social Policy, University of Economics, Prague (zdenek.pikhart@vse.cz). 
only, therefore we could not carry out a comparison with, for example, other V4 economies, and second, the amount of output would be rather extensive for a typical paper even if we performed the analysis on a smaller scale.

Three measures of financial markets' risk are considered in the analysis: money market, capital market and foreign exchange market risk. The discussion of the construction and estimation of the measures is left out for the moment. The output of the impulse-response analysis within the SVARs shows that in most cases the results are qualitatively as expected as far as point estimates are concerned and usually they are significant at 5\% level. The outcomes might be interpreted as follows: the financial markets' risk rather play a role as an amplifier within other mechanisms, but considered on its own, they do not have a potential to cause such significant disturbances to the development of the variables of the real economy as one can see in reality. We suppose that the assessment of the mechanisms themselves should be carried out within full-fledged structural models and so we do not pursue such an analysis in this paper.

The paper is structured as follows. The first part presents an overview of the "financial accelerator" approach and other approaches usually considered in the analysis of the interrelations between financial and real economy. The role of financial risk is stressed throughout the theoretical summary, however, no formal model is formulated here as no formal model in the sense of economic theory is tested in the paper. It should be stressed right at the beginning that the financial risk might affect both demand and supply sides of the economy. The second part of the paper presents data used in the analysis and methods indicating how the variables of financial markets' risk were derived. Also basic description of the financial risk variables is given to set the ground for the interpretation of the output of the SVAR analysis. The SVAR models, whose results are presented in the next part, are also introduced in the second part of the paper, especially with regard to the variables they contain and with regard to the constrains we used in the set-up. The third part of the paper presents the results of the impulse-response analysis within the SVARs as introduced in the previous part. The fourth part of the paper summarizes the key results of the empirical analysis.

\section{Theoretical Background}

From the point of view of modern macroeconomics the key element of the theory of interaction between financial markets and real economy is the model of financial accelerator.

The model is based on the contributions of Bernanke and Gertler (1995), Bernanke et al. (1996) and Kiyotaki and Moore (1997). Bernanke et al. (1999) introduced the concept into a dynamic general equilibrium model. Krishnamurthy (2010) and Bijlsma et al. (2010) give a concise overview of this approach. Originally, the contributions by Bernake (et al.) were concerned with the effects of monetary policy on real variables rather than on the effects of financial markets on a real economy and vice versa. The fundamental idea from the point of view of this paper rests on the hypothesis that a shock to asset prices in terms of their decline reduces net worth of nonfinancial firms, which due to informational inefficiencies of credit markets makes banks cut down on the supply of loans. This limits production of those firms (limits real activity of the economy) and reduces the value of firms' assets. This in turn further pushes down the value of net worth etc. One of the first applications of this idea in case of households, which then constitutes 
a link between financial markets and private consumption, was introduced by Ludvigson (1999). Brunnermeier and Pedersen (2009) consider explicitly the role of volatility of assets' prices in this mechanism.

It is important to note that the value of net worth may be influenced by the development of money market and foreign exchange market, not only directly by capital market. An increase in interest rates raises the interest on debt paid by nonfinancial firms and thus reduces net worth. Increases in interest rates on money markets are closely linked with increases in spreads between rates of various maturities and institutional background (e.g. a spread between short term money market interest rate and central bank monetary policy rate). An increase in money market spreads (increase in money market risk) may not only directly affect net worth via higher interest payments but also indirectly through the influence on required yield on capital assets (equity). Typically, money market spread is a basic piece of information for the estimation of required yield on equity as used by practitioners to evaluate (nonfinancial) firms. Increase in money market spreads thus may, through the effect on required yield on equity in terms of its increase, further deteriorate the value of net worth.

The relationship between capital assets' volatility and its returns has long been an issue of financial economics. Portfolio theory derives a positive relationship, e.g. Cuthbertson and Nitzsche (2005) for a review of financial economics. One of the first empirical analyses was provided by Black (1976). Ghysels et al. (2005) confirms the hypothesized positive relationship between expected volatility and expected returns. Such a relationship may feed into the mechanism outlined above. An increase in capital market risk (increase in the volatility of capital assets' returns) is accompanied by the increase in expected returns with the potential of reducing the value of net worth.

These effects may be accompanied by the considerations about exchange rate volatility. Given the nonfinancial firm owns assets denominated in foreign exchange or is indebted in foreign exchange, changes in exchange rate may reduce the value of net worth. Caballero and Krishnamurthy (2003) analysed the effects of exchange rate volatility on foreign-indebted agents. The relationship between the volatility of returns on foreign exchange rate and changes in exchange rate is ambiguous. There is no theoretical underpinning that would claim that higher volatility of relative changes in exchange rate (returns on exchange rate) must be accompanied by exchange rate appreciation or depreciation.

Another key theoretical element is the effect of financial markets on banks' balance sheets and so their ability and willingness to supply credit to nonfinancial firms (and possibly households) as proposed by Bernanke and Blinder (1988). From the point of view of today's macroeconomic theory and also the reality of the recent financial crises it is more relevant to consider a variant of the financial accelerator model in the context of banks and banking market rather than the original formulation introduced by Bernanke and Blinder (1988), which was discussed especially in the 1990s. Van den Heuvel (2006) presents a model of financial accelerator applied to the banking sector. Gertler and Kiyotaki (2010) give a concise model where the idea of financial accelerator is applied in the context of the interbank market. Looked upon this way, the ideas about the effects of financial risk originating in money, capital and foreign exchange market on net worth may be applied here in exactly the same way. Increased financial risk may therefore reduce net worth of banks, which limits the amount of credit the banks supply to nonfinancial firms 
and households, on the one hand, and on the other hand, it also limits the amount of credit a bank may obtain from another bank on the interbank market, thus increasing possible risk of a bank going bankrupt as shown in the paper by Gertler and Kiyotaki (2010).

The third theoretical mechanism, which should be taken into account, is a direct role of increased risk on investment activity, i.e. outside the model of financial accelerator. The direct effects of financial markets on investments are usually considered outside the dynamic general equilibrium model as the simple Q-theory, e.g. Hayashi (1982), does not seem to be adequate to capture the problem. Caballero (1997) gives a nice overview of issues of adjustment and irreversible costs and their effects on investment activity. Matsuyama (2007) differentiates investment according to productivity and shows that capital market shocks may have various effects on investment activity. Considering the mechanisms outlined above, an increase in money market spreads and/or increase in volatility of capital assets' returns may directly translate into higher required returns on investment projects and thus render many investment projects unprofitable during a crisis. Probably the most general approach to the problem was proposed by Pindyck (1988), accompanied by a follow-up by Caballero (1991), who applied option theory to the investment decision-making process. Generally, an increase in uncertainty (regardless of its source) raises the value of an option to wait on an investment project whenever the investment project may be postponed by the firm. A higher value of an option to wait would have to be matched by a higher value of the investment project for the project to be accepted right away, which is improbable in times of crises. Thus all three risks, coming from money market, capital market and foreign exchange market, may dampen investment activity during bad times.

There is a vast amount of empirical literature on financial accelerator. Moody and Taylor (2003) using VAR found significant reactions of real variables to changes in yield spreads. On the other hand, Chari et al. (2007) found limited support for financial accelerator. An important study from the point of view of the presented analysis comes from van Aarle et al. (2003) who showed that the effects of monetary policy are rather diversified across the EU countries. Vermeulen (2000) finds some support for financial accelerator mechanism in some of the EU countries.

Fidrmuc et al. (2010) find support for the mechanism in case of the Czech economy based on panel analysis of several hundreds of nonfinancial firms. Eickmeier et al. (2006) focus on the relationship between credit and macroeconomic fluctuations in Germany (and also some other European economies) finding support for such considerations. Pellényi (2012) shows quite diversified impact of monetary policy on various sectors of Hungarian economy pointing to the fact that the effects of financial accelerator mechanism may also be rather differentiated and thus it might be hard to capture those using macroeconomic aggregates. Ahtik (2012) used panel data consisting of banks and showed support for the bank lending channel in Slovenia. Beneš et al. (2009) constructed a dynamic stochastic general equilibrium model for an emerging economy where they analysed the effects of increased money market premia (domestic, foreign) on real variables. They showed the real effects may be quite pronounced, however, their model was not calibrated to any actual emerging economy. Finally, Ryšánek et al. (2011) use a dynamic intertemporal model with financial frictions to analyse possible reactions of monetary policy to financial shocks. 


\section{Data and Methodology}

\subsection{Real variables}

To capture the behaviour of the real economy, quarterly data on real GDP, structure of household consumption and firm investment, credit and CPI (consumer price index) were retrieved from the Czech Statistical Office and Czech National Bank database. The data were seasonally adjusted. The sample runs from the first quarter 1996 to the second quarter 2012. All the data except for credit were found stationary by the augmented Dickey-Fuller (ADF) test after being log-differenced. The log-differenced CPI series is in this analysis understood as a measure of inflation. Finally, none of the variables, except for consumption of nondurables and investment in other buildings, have normal distribution according to the Jarque-Bera test.

We rely on the log-differenced transformation for two reasons. First, although we realize it would be much interesting to carry out cointegration analysis and examine short-run and long-run dynamics of the systems, the ambiguity of the preliminary results pointed to the fact that the length of the series is too short (also relative to the number of the series) to perform a meaningful analysis of this type. Second, as far as VAR models are concerned it has long been understood, Hamilton (1994), that it is the stationarity of VAR itself and not necessarily the series that matters, in other words VAR may be estimated with unstationary series in levels. Based on our experience with working with financial time series we, however, prefer the log-differenced transformation to obtain stationary series. 
Table 1 | Descriptive Statistics

\begin{tabular}{|c|c|c|c|c|c|}
\hline \multirow[t]{2}{*}{ variable } & code in VARs & mean & $\begin{array}{c}\text { st. } \\
\text { deviation }\end{array}$ & Jarque-Bera & ADF \\
\hline & \multicolumn{5}{|c|}{ first log-differenced } \\
\hline $\begin{array}{l}\text { real gross domestic } \\
\text { product }\end{array}$ & OUTPUT & 0.00703 & 0.00937 & $85.144^{* * *}$ & $-3.09406^{* *}$ \\
\hline $\begin{array}{l}\text { households } \\
\text { consumption } \\
\text { of durable and } \\
\text { semidurable goods }\end{array}$ & DURABLE & 0.01336 & 0.02418 & $11.464^{* * *}$ & $-5.63717^{* * *}$ \\
\hline $\begin{array}{l}\text { households } \\
\text { consumption } \\
\text { of nondurable } \\
\text { goods and services }\end{array}$ & NONDURABLE & 0.00395 & 0.00986 & 17.994 & $-8.24458^{* * *}$ \\
\hline $\begin{array}{l}\text { investment in } \\
\text { dwellings }\end{array}$ & DWELLINGS & -0.00102 & 0.05768 & $7.734^{* *}$ & $-7.65961^{* * *}$ \\
\hline $\begin{array}{l}\text { investment } \\
\text { in machinery } \\
\text { and transport } \\
\text { equipment }\end{array}$ & MACHINERY & 0.00956 & 0.05285 & $8.675^{* *}$ & $-6.68409 * * *$ \\
\hline $\begin{array}{l}\text { investment in other } \\
\text { buildings and } \\
\text { structures }\end{array}$ & BUILDINGS & -0.00183 & 0.03112 & 3.06 & $-6.88265^{* * *}$ \\
\hline $\begin{array}{l}\text { gross domestic } \\
\text { product of Germany }\end{array}$ & OUTPUT_DE & 0.00322 & 0.00891 & $271.640^{* * *}$ & $-4.75684^{* * *}$ \\
\hline total credit & CREDIT & 0.01119 & 0.03773 & $283.788^{* * *}$ & -2.49465 \\
\hline $\begin{array}{l}\text { total credit of } \\
\text { households }\end{array}$ & CREDIT_H & 0.0408 & 0.03376 & $13.248^{* * *}$ & -2.48804 \\
\hline total credit of firms & CREDIT_F & -0.00056 & 0.03927 & $272.193^{* * *}$ & -2.52923 \\
\hline inflation based on & CPI INFLATION & 0.00728 & 0.00755 & $127.918^{* * *}$ & $-4.45175^{* * *}$ \\
\hline Brent oil price & OIL & 0,03358 & 0.1481 & $134.429^{* * *}$ & $-5.24257^{* * *}$ \\
\hline $\begin{array}{l}\text { nominal exchange } \\
\text { rate of CZK to EUR }\end{array}$ & $\begin{array}{l}\text { EXCHANGE } \\
\text { RATE }\end{array}$ & -0.00716 & 0.02549 & $23.896^{* * *}$ & $-6.52284^{* * *}$ \\
\hline $\begin{array}{l}\text { difference between } \\
\text { Pribor3M and } \\
\text { Repo2W }\end{array}$ & SPREAD3M & 0.00343 & 0.00411 & $96.591 * * *$ & $-3.03586^{* *}$ \\
\hline $\begin{array}{l}\text { variability of returns } \\
\text { to capital market }\end{array}$ & CM_RISK & 0.00367 & 0.00172 & $166.394^{* * *}$ & $-3.20413^{* *}$ \\
\hline $\begin{array}{l}\text { variability of } \\
\text { returns to nominal } \\
\text { exchange rate }\end{array}$ & ER_RISK & 0.00023 & 0.00014 & $94.702 * * *$ & $-2.80920^{*}$ \\
\hline
\end{tabular}

Notes: JB is Jarque-Bera statistic under the null of normal distribution. ADF is augmented DickeyFuller statistic under the null of unit root. $\left({ }^{*},{ }^{* *},{ }^{* * *}\right.$ denote rejection of the null at $10 \%, 5 \%$ and $1 \%$ level of significance, respectively). 


\subsection{Risk measures}

Three measures of financial markets' risk were used. The money market risk is captured by the difference between the three-month money market rate and the two-week policy rate of the Czech National Bank (REPO rate). The difference describes the interbank mark-up over the policy rate, which is typically further reflected in other interest rate spreads. Figure 2 below indicates that the measure significantly increased during the two most prominent negative shocks that so far have affected the Czech economy. The measure of money market risk was found stationary at $5 \%$ level of significance by the ADF test.

In the case of the capital and foreign exchange market risks we resort to the estimation of the time-varying variance of the innovation to the price/return process in each respective case. This method of constructing risk measures closely follows the approach of Huizinga (1993). The capital market risk was estimated with a GARCH model applied to monthly data on the capital market index as retrieved from the Prague Stock Exchange database (Index PX). The GARCH was run on logarithmic monthly changes of the index. GARCH $(1,1)$ with an autoregressive element of one lag in the mean equation was used. Such a structure leads to well-behaved residuals of the estimated GARCH models. The capital market risk was then defined as the estimated conditional variance of the monthly returns on the index within the GARCH model. For the purpose of the analysis quarterly averages of the estimated conditional variance are used in the SVAR models. The measure was found to be stationary at $5 \%$ level of significance by the ADF test. Identical approach was taken in the case of foreign exchange risk. In the case the procedure was applied to logarithmic monthly changes in the exchange rate of CZK/EUR.

\section{Figure 1 | Capital Market Risk}

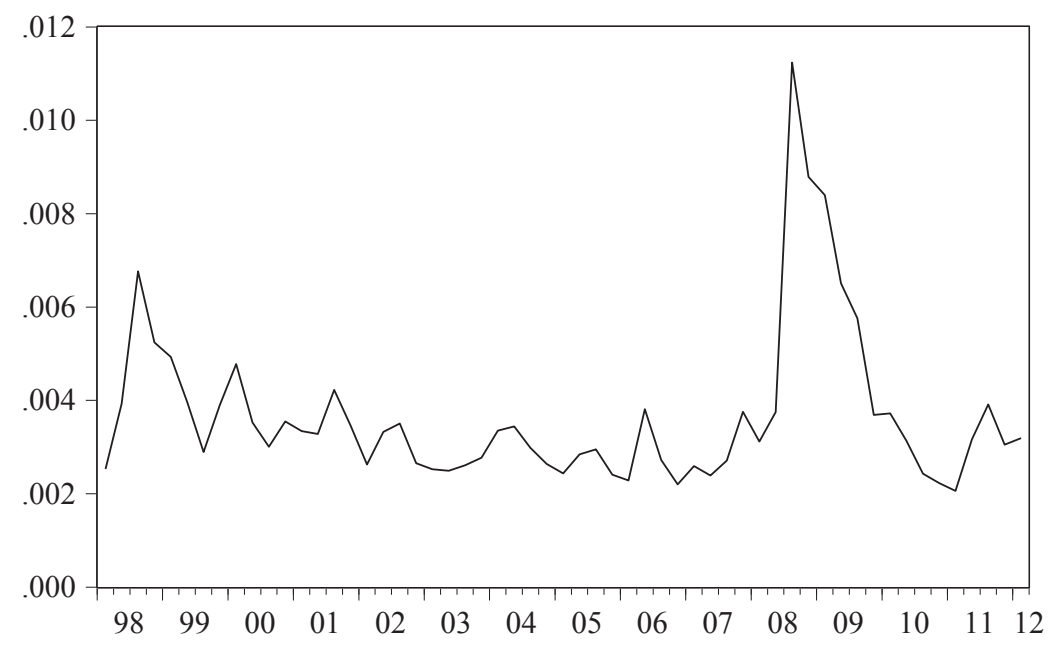

Notes: estimated conditional variance of relative changes in the PX index. 
Capital market risk rose distinctively in the second half of 2008 and subsequently decreased to pre-crisis values in 2009. It was predominately caused by the market crash after Lehman Brothers' bankruptcy, which uncovered the balance sheet problem with non-performing mortgage loans. This strong negative shock was spread out around the world financial markets. It complies with the same development of risk in money and foreign exchange market in 2008-2009.

Beside the 2008-2009 turbulences when looking at the more distant history, there was an escalation of a bank crisis in the Czech Republic in 1998. Banks accumulated high volume of non-performing investment loans in the time between the Velvet Revolution in 1989 and privatization of the industry and banking sector. State banks kept many uncompetitive companies on the market and consequently many banks were close to going bankrupt. The Government established a consolidation agency to avoid disintegration of the overall banking system. We think that this was one of the factors which contributed to the 1998 recession (besides inappropriate fiscal-monetary policy mix and external financial shocks coming from Southeastern Asia). The negative risk shock is evident on all three markets in Figures 1-3.

There is one more episode to be noticed and this one is related solely to the foreign exchange market. Czech National Bank carried out its last foreign exchange intervention in 2002 with the aim of currency devaluation. This is clearly reflected in Figure 3.

Figure 2 | Money Market Risk

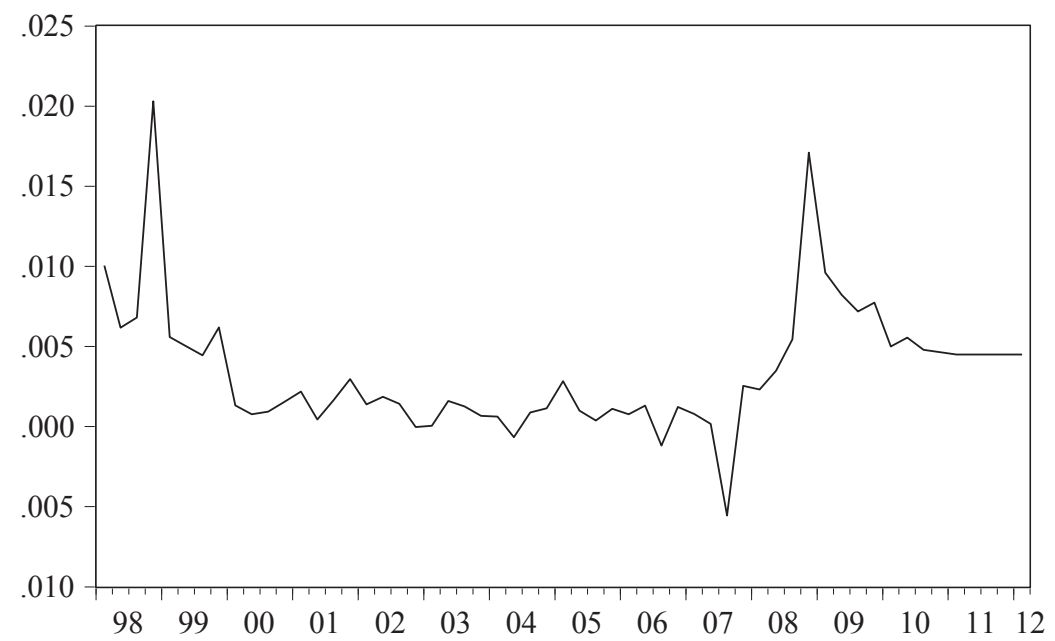

Notes: difference between 3M Pribor and 2W Repo. 


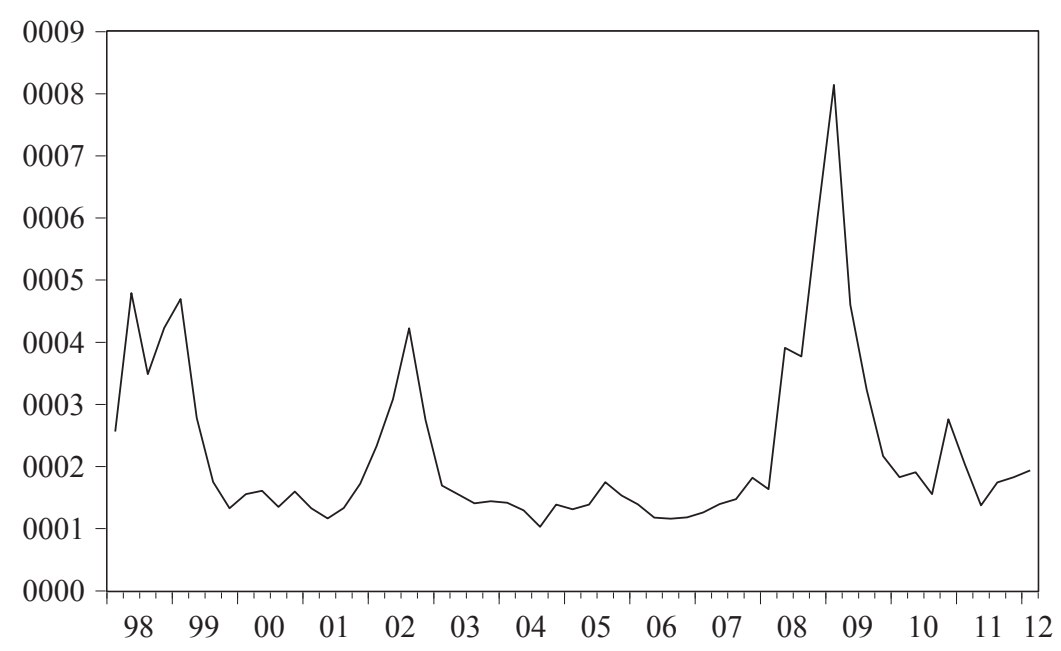

Notes: estimated conditional variance of relative changes in the CZK/EUR exchange rate.

\subsection{SVAR models}

Following Lutkepohl (2005), let's assume an underlying structural model of an economy in the form:

$$
\mathbf{A y}_{t}=\mathbf{A}_{1}^{*} \mathbf{y}_{t-1}+\ldots \mathbf{A}_{p}^{*} \mathbf{y}_{t-p}+\boldsymbol{\varepsilon}_{t}
$$

where $\mathbf{y}$ is a vector of $K$ endogenous variables, $\boldsymbol{\varepsilon}$ is a vector of structural innovations and $\mathbf{A}$ and $\mathbf{A} *$ are $K x K$ matrices of coefficients. We do not consider exogenous variables in (1) for the sake of simplicity, however, we do use them in the actual estimations. The variance covariance matrix of the structural innovations is assumed to be orthonormal. The underlying model (1) is unknown. What is being estimated is the reduced form of (1):

$$
\mathbf{y}_{t}=\mathbf{A}_{1} \mathbf{y}_{t-1}+\ldots \mathbf{A}_{p} \mathbf{y}_{t-p}+\mathbf{u}_{t},
$$

where $\mathbf{A}$ are $K x K$ matrices of coefficients and $\mathbf{u}$ is a vector of innovations, which are not autocorrelated. The VAR (1) must be stationary. The shocks contained in vector $\mathbf{u}$ have no direct interpretation. However, from (1) and (2) it follows:

$$
\begin{gathered}
\mathbf{A}_{j} \quad \mathbf{A}{ }^{1} \mathbf{A}_{j}^{*}, \\
\boldsymbol{\Sigma}_{\varepsilon}=\mathbf{A} \sum_{\mathbf{u}} \mathbf{A}^{\prime},
\end{gathered}
$$

where $\Sigma$ denotes a variance covariance matrix. Therefore, constraining the coefficients of matrix A yields a decomposition of the variance covariance matrix of the innovations of the reduced form system so that they can be related to the structural innovations in (1). The coefficients of matrix $\mathbf{A}$ describe the contemporaneous relations between the endogenous variables. This is the so-called A-model. Regarding the assumption of 
orthonormal variance covariance matrix of structural innovations in (1), the matrix equation (4) contains $K(K-1) / 2$ independent equations. To obtain a unique solution for the $K^{2}$ coefficients of matrix A, one needs to impose another $K(K+1) / 2$ restrictions on $\mathbf{A}$. Diagonal elements of matrix $\mathbf{A}$ are typically restricted to 1 . This means that another $K(K-1) / 2$ restrictions are needed.

We perform the analysis in several steps:

- we estimate the reduced form and we choose the number of lags so that the residuals are not autocorrelated;

- in the next step we restrict the matrix A so that its diagonal elements are 1 and also we set all the coefficients describing contemporaneous relationships between real variables themselves and between real variables and financial factors to zero; i.e. we allow contemporaneous effects only among financial variables - this approach is based on the theories of nominal and real rigidities;

- in the next step, the structural decomposition is performed; in all of the cases the system is over-identified, therefore we test the over-identification by comparing likelihood of the unrestricted and restricted (over-indentified) model;

- in the final step we perform Monte Carlo integration to obtain the impulse response functions and compute significance bands at $5 \%$ level.

Table 2 shows the structure of the underlying VAR models. It gives information on the endogenous and exogenous variables used in each particular VAR. The estimations are based on 57 observations; 2 lags were sufficient to get rid of autocorrelation in the residuals. The VAR1 is the baseline model capturing the real economy and money/credit market. We added the output of the German economy and the price of oil to reflect the position of the Czech economy as an open and small one. This model is used to capture the effect of a real external shock and it serves to check the economic plausibility of the structure used in the paper.

Although the choice of the variables is not directly "examined", the structure of the model corresponds to the structure that can be frequently found in the VAR literature focused on business cycle analysis. Basically, it estimates the dynamics of output and inflation in the traditional context of the ad hoc AD-AS model. Since the model should reflect the practice of inflation targeting, it does not include a monetary aggregate, but contains a measure of interest rates; here as a spread, which is given by the overall target of this analysis. Since the model relates to the case of a small and open economy, the system accounts for exchange rate, which can, however, be directly influenced by domestic factors, therefore we include it as a endogenous variable. We also include other external variables: output of the German economy and the price of oil, but in this case as external variables, since the effect of the Czech economy on these variables is absolutely negligible. 
Table 2 | Structure of the VAR Models

\begin{tabular}{|c|c|c|c|c|}
\hline \multirow{10}{*}{$\begin{array}{l}\text { endogenous } \\
\text { variables }\end{array}$} & VAR1 & VAR2 & VAR3 & VAR4 \\
\hline & OUTPUT & OUTPUT & DURABLE & MACHINERY \\
\hline & INFLATION & INFLATION & NONDURABLE & BUILDINGS \\
\hline & EXCHANGE_RATE & EXCHANGE_RATE & DWELLINGS & INFLATION \\
\hline & CREDIT & CREDIT & INFLATION & EXCHANGE_RATE \\
\hline & SPREAD3M & SPREAD3M & EXCHANGE_RATE & CREDIT_F \\
\hline & & CM_RISK & CREDIT_H & SPREAD3M \\
\hline & & ER_RISK & SPREAD3M & CM_RISK \\
\hline & & & CM_RISK & ER_RISK \\
\hline & & & ER_RISK & \\
\hline \multirow{3}{*}{$\begin{array}{l}\text { exogenous } \\
\text { variables }\end{array}$} & DUMMY & DUMMY & DUMMY & DUMMY \\
\hline & OUTPUT_DE & OUTPUT_DE & OUTPUT_DE & OUTPUT_DE \\
\hline & OIL(-1) & OIL(-1) & OIL(-1) & OIL(-1) \\
\hline observations & 57 & 57 & 57 & 57 \\
\hline lags & 2 & 2 & 2 & 2 \\
\hline \multirow{5}{*}{$\begin{array}{l}\text { LM test for } \\
\text { autocorrelation } \\
\text { (lags } 1 \text { - 5) }\end{array}$} & 33,073 & 61,395 & 46,687 & 31,852 \\
\hline & 34,321 & 48,005 & 44,730 & 41,597 \\
\hline & 21,482 & 43,824 & 45,612 & $48,687^{*}$ \\
\hline & 25,819 & 57,719 & 52,442 & 43,960 \\
\hline & 19,152 & 48,523 & 56,067 & 41,804 \\
\hline Jarque-Bera & $35,431^{* * *}$ & $62,655^{* * *}$ & $89,080^{* * *}$ & $39,799 * * *$ \\
\hline White & 377,393 & 947,609 & 888,662 & 567,92 \\
\hline LR test & $8,413^{* *}$ & $22,859 * *$ & $57,960 * * *$ & $27,234^{*}$ \\
\hline
\end{tabular}

Notes: LM statistic is based on Lagrange multiplier test for autocorrelation under the null of no autocorrelation up to the given lag. Jarque-Bera is the Jarque-Bera statistic under the null of multivariate normal distribution (Cholesky decomposition used). White is the White statistic under the null of no heteroskedasticity. LR test statistic is based on comparison of log likelihood of the unrestricted model (null hypothesis) and restricted model (alternative hypothesis) $\left({ }^{*},{ }^{* *},{ }^{* * *}\right.$ denote rejection of the null at $10 \%, 5 \%$ and $1 \%$ level of significance, respectively).

We test the adequacy of the models with respect to the behaviour of the residuals of the model: the question of autocorrelation, normality and homoskedasticity of the residuals. The economic relevance of the output is analysed through the traditional impulse-response functions, which may be qualitatively compared with the theoretical 
conclusions of the relevant economic theory, which we presented in the beginning of the paper. Typically the results of the VAR analysis, of what can be "seen" in the real data, may be compared with the structural analysis. To perform both is out of the reach of this contribution, but the reader may at least qualitatively compare the relevance of the financial market in the propagation of shocks consulting the paper by Ryšánek et al. (2011). They also show that, especially in the sense of the financial accelerator mechanism, the financial market amplification of the macroeconomic-financial shocks may be, in the case of the Czech Republic, rather limited.

VAR2 is a modified version of VAR1 with capital market risk and foreign exchange risk. VAR3 contains a decomposition of the household consumption and household credit is used instead of total credit. We examine a relationship between a decomposition of firm investment and firms' credit in VAR4. We do not report graphical output for VAR3 and VAR4 and resort to only verbal description as we could see that due to the larger number of variables used the results are less robust than in VAR1 and VAR2.

We rejected the null hypothesis of multivariate normal distribution of the residuals by the Jarque-Bera test. We did not observe statistically significant heteroskedasticity in any of the VARs.

We test the "null" restrictions, which preclude contemporaneous interactions between real variables and contemporaneous reactions of real variables on financial variables by the LR test. The LR test is also reported in the table, and is based on the log likelihood of the unrestricted (VAR) model and the log likelihood of the restricted (SVAR) model. The null of the unrestricted model was rejected at 5\% significance level for VAR1 and VAR2 and at $1 \%$ and $10 \%$ in cases of VAR3 and VAR4, respectively.

\section{Results}

\subsection{Real external shock in the underlying model}

Figure 4 presents the results of the impulse-response analysis within VAR1. The shock was performed by increasing the German output by 1 standard deviation. Real external shocks affect the output of the Czech economy significantly through demand for the Czech exports and Figure 4 shows a highly significant increase in the Czech output. The increase in output is accompanied by appreciation of the foreign exchange rate as shown in Figure 4 and as the effects of the positive shock diminish it reverses to a slight depreciation significant at $10 \%$ after two quarters. The effects on inflation are insignificant and in case of credit there is a slight lagged increase and significant at $10 \%$ level. Interest rate spread behaves pro-cyclically and is significantly reduced by the positive economic development. 
Figure 4 | VAR1 - Positive Shock to German Output
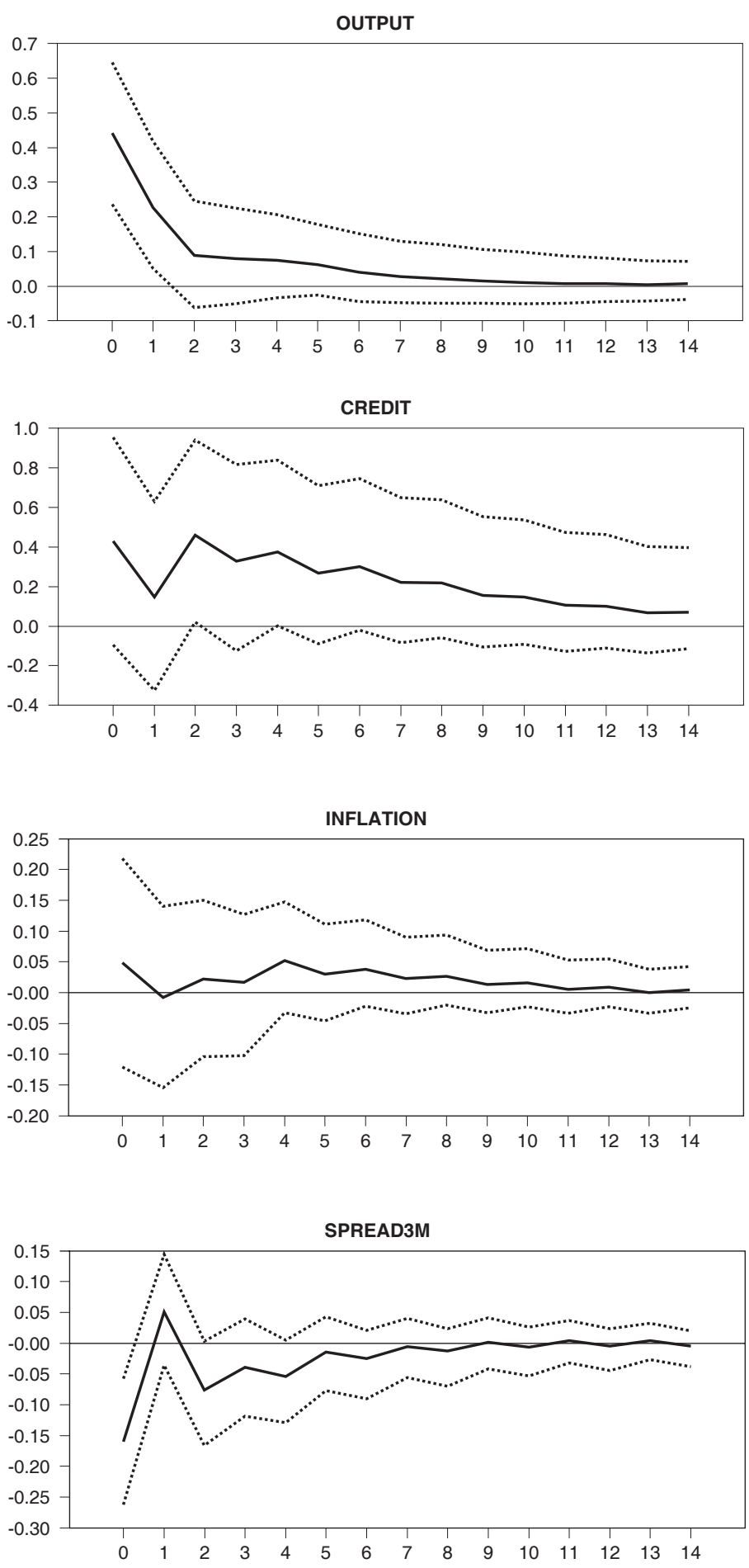


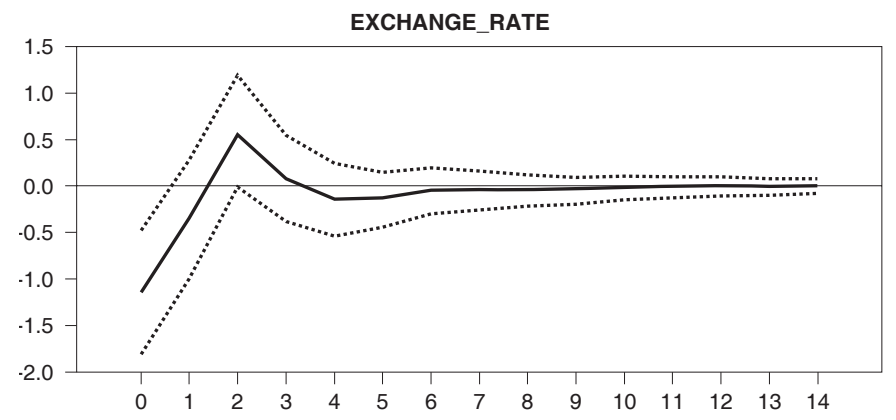

Notes: Significance bands at $5 \%$ level.

\subsection{Shock to capital market risk}

Now we proceed to the second model: VAR2. This is VAR1 enhanced by the capital market and foreign exchange measures of risk. We perform 3 analyses within this model, which differ in the risk measure being shocked. Figure 5 gives the result for the positive shock to capital market risk. The increase of capital market risk was reflected negatively by an increase in money market risk and foreign exchange risk (significant at $10 \%$ ). This is further accompanied by exchange rate depreciation, also significant at $10 \%$. Higher capital market risk is associated with a decrease in output. The reaction of inflation and especially credit is insignificant. The increase of the spread and exchange rate depreciation may seem puzzling at first, but one should not confuse the short-run effects of interest rates on the exchange rate as given by the uncovered interest rate parity condition with changes in the spread and their possible effects on exchange rate.

Figure 5 | VAR2 - Positive Shock to Capital Market Risk
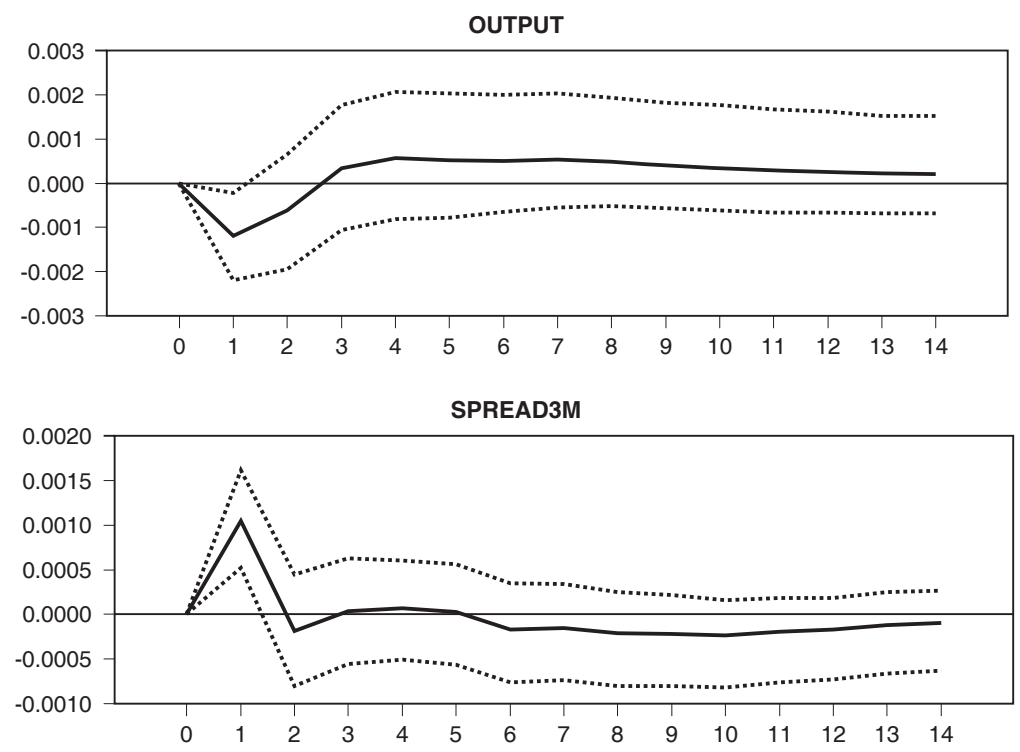
Figure 5 | continuation

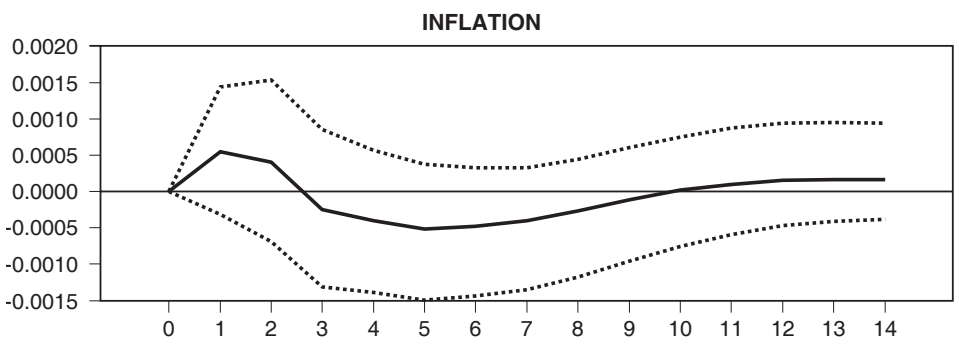

CM_RISK
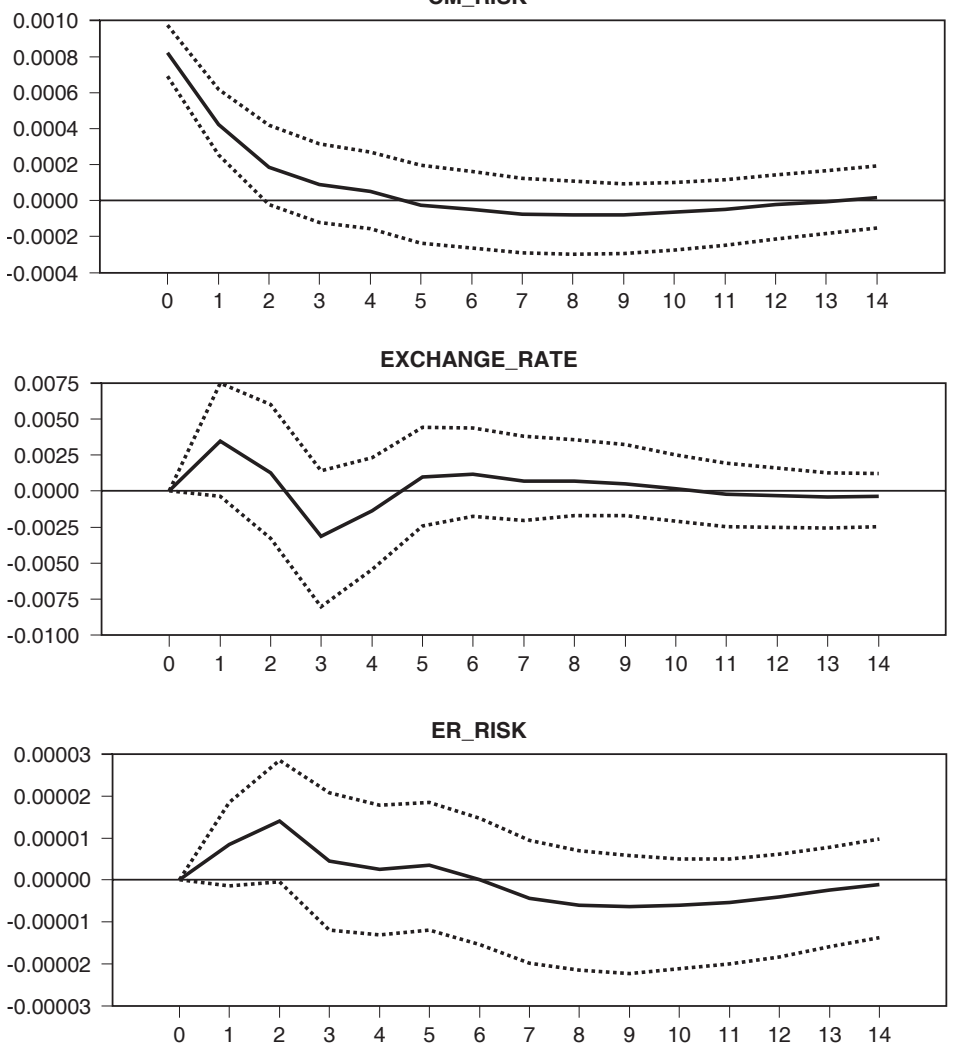

CREDIT

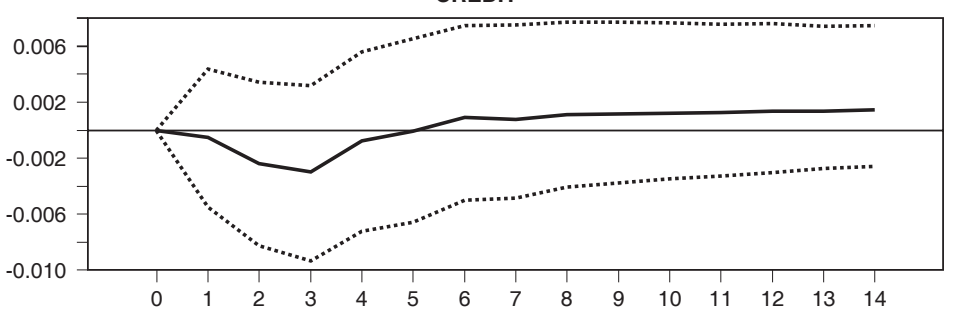

Notes: Significance bands at 5\% level. 


\subsection{Shock to foreign exchange risk}

Figure 6 captures the effects of a positive shock to foreign exchange risk. The foreign exchange risk does not affect significantly either money market risk or capital market risk. Higher volatility of exchange rate influences negatively the output, but only at $10 \%$ level of significance. Furthermore, the development of output is soon reversed. The effects on credit and inflation are insignificant. Slight exchange rate depreciation is detected at $10 \%$ level of significance. All in all the effects of a shock to exchange rate risk seem to have much smaller impact on the economy than the changes in the measure of capital market risk.

Figure 6 | VAR2 - Positive Shock to Foreign Exchange Risk
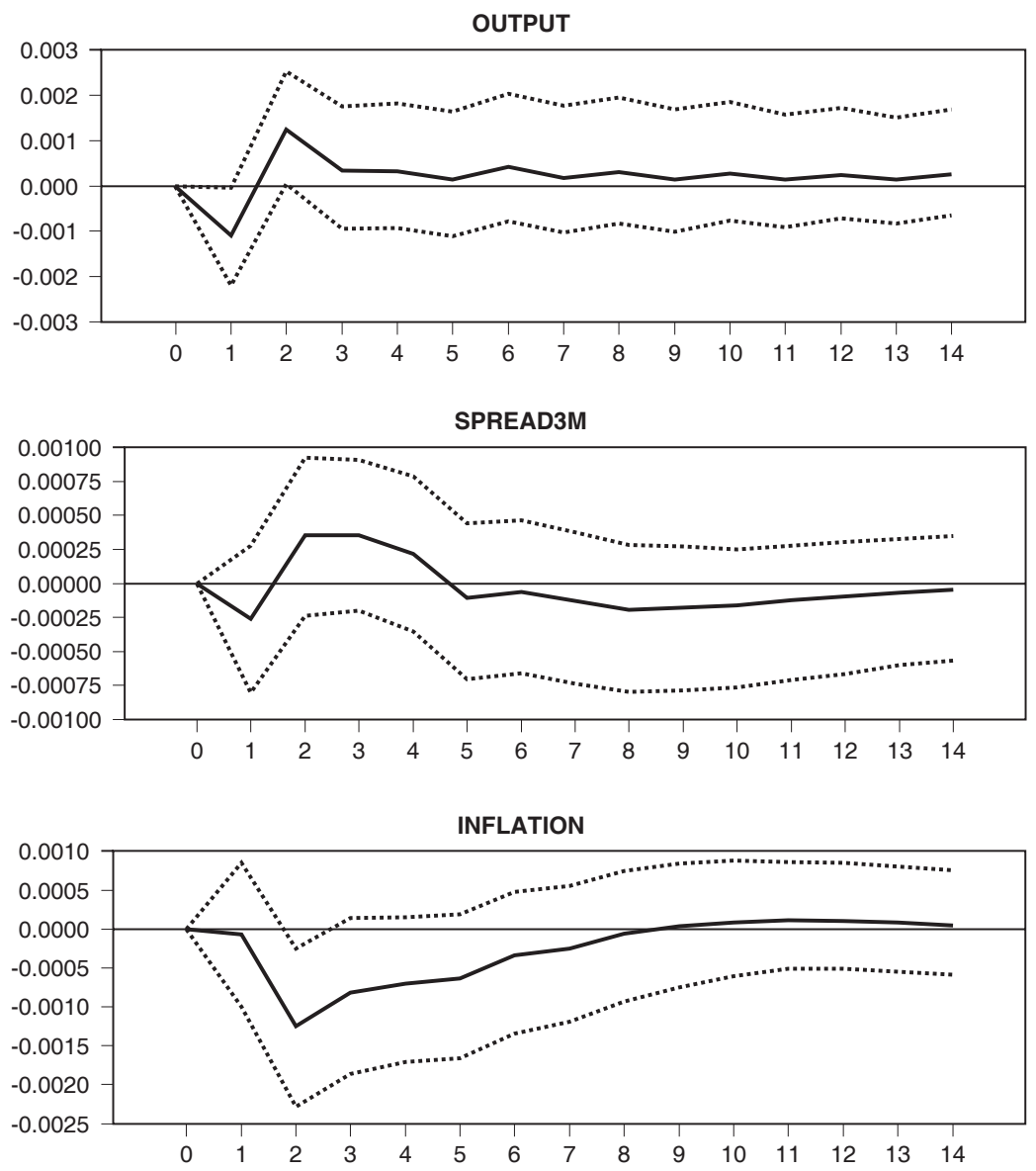


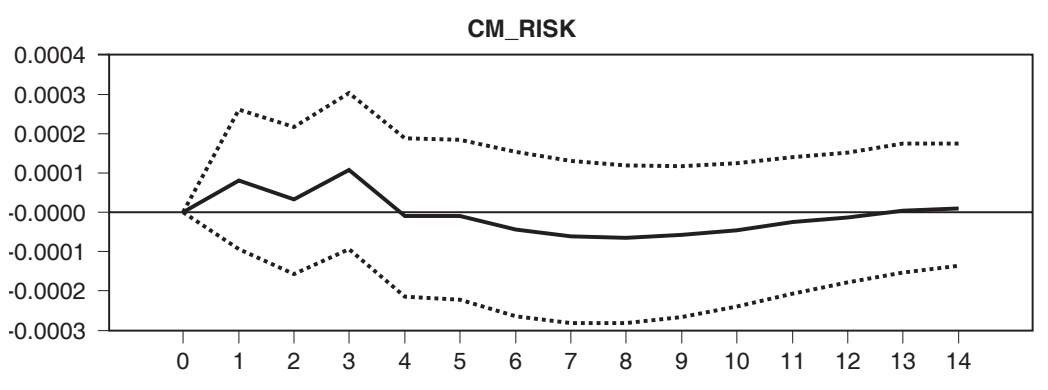

EXCHANGE_RATE

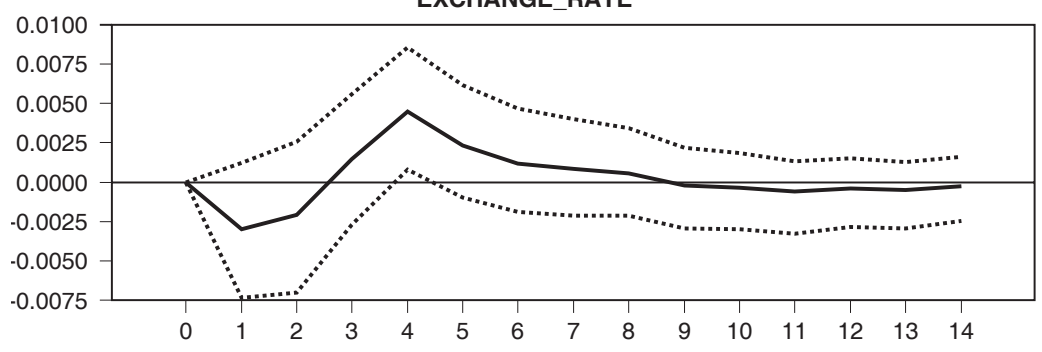

ER_RISK

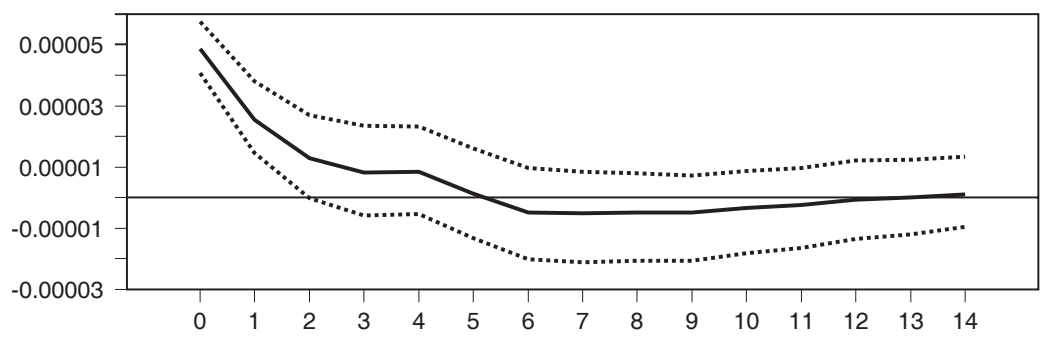

CREDIT

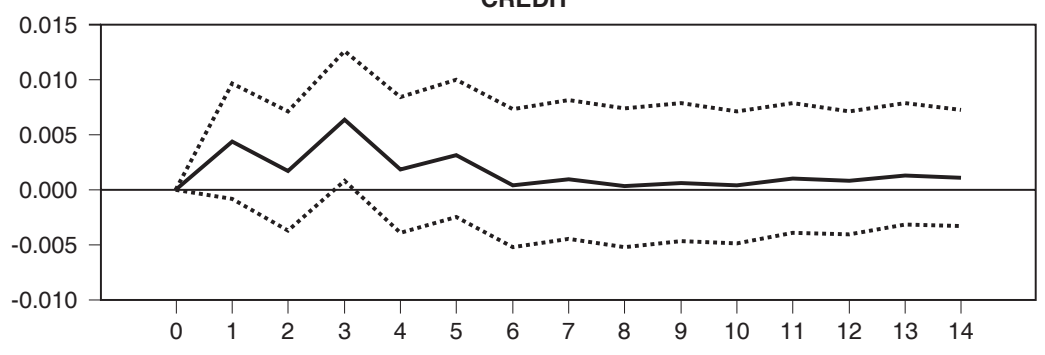

Notes: Significance bands at 5\% level.

\subsection{Shock to money market risk}

Figure 7 presents the impulse-response analysis in the case of a positive shock to money market risk. The effects of a shock to the money market risk are the strongest we have detected. Output is heavily negatively affected by the increase in money market spread. 
The shock is relatively deep and persistent. This output fall is accompanied by a lower credit activity of commercial banks which might further adversely influence the output components. Capital market risk and foreign exchange risk are obviously influenced as well; capital market risk increases at $10 \%$ level of significance. On the other hand, the effect on inflation is insignificant. Exchange rate tends to appreciate at $10 \%$ level of significance, but this is soon reversed to depreciation.

\section{Figure 7 | VAR2 - Positive Shock to Money Market Risk}
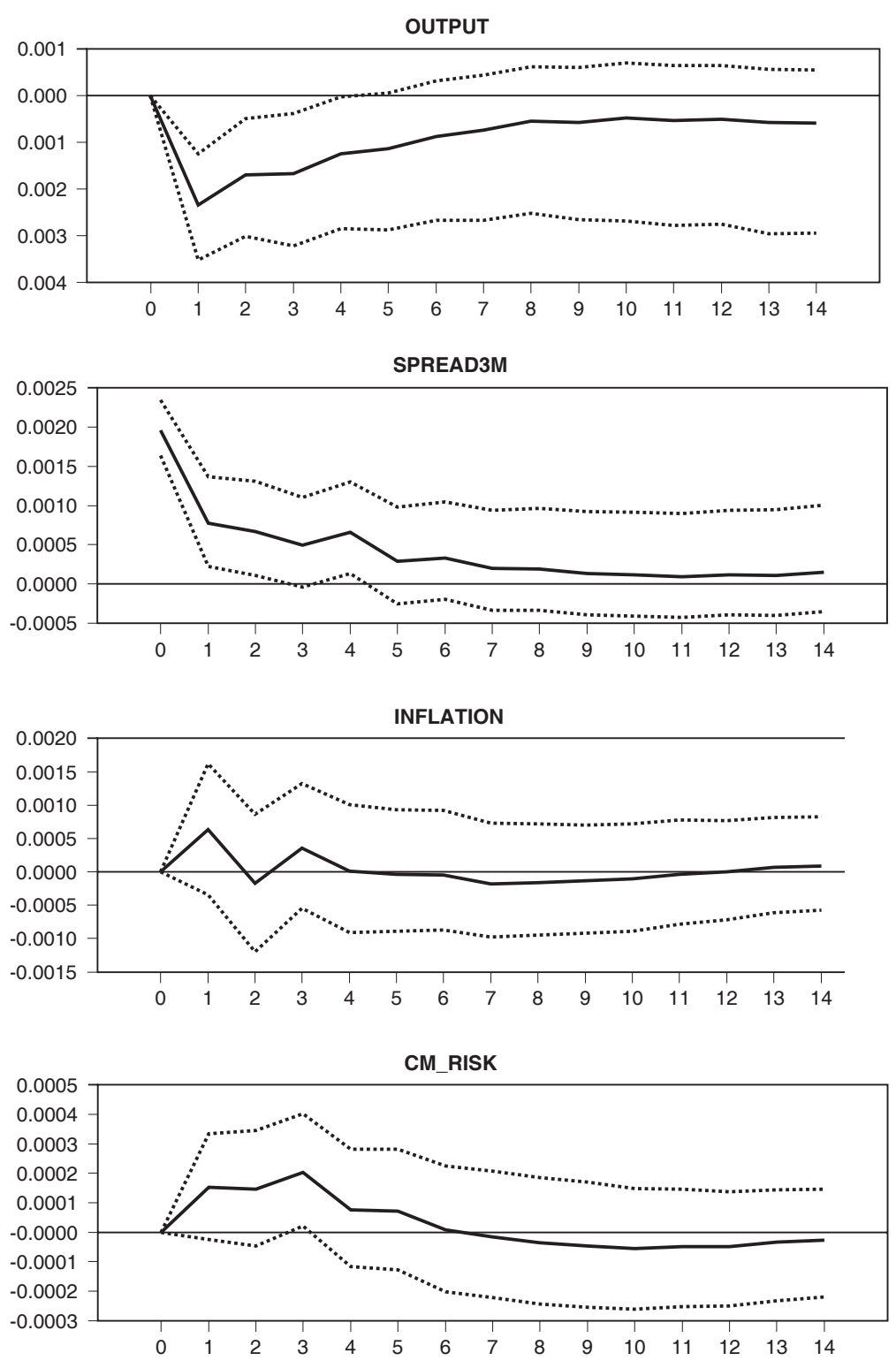

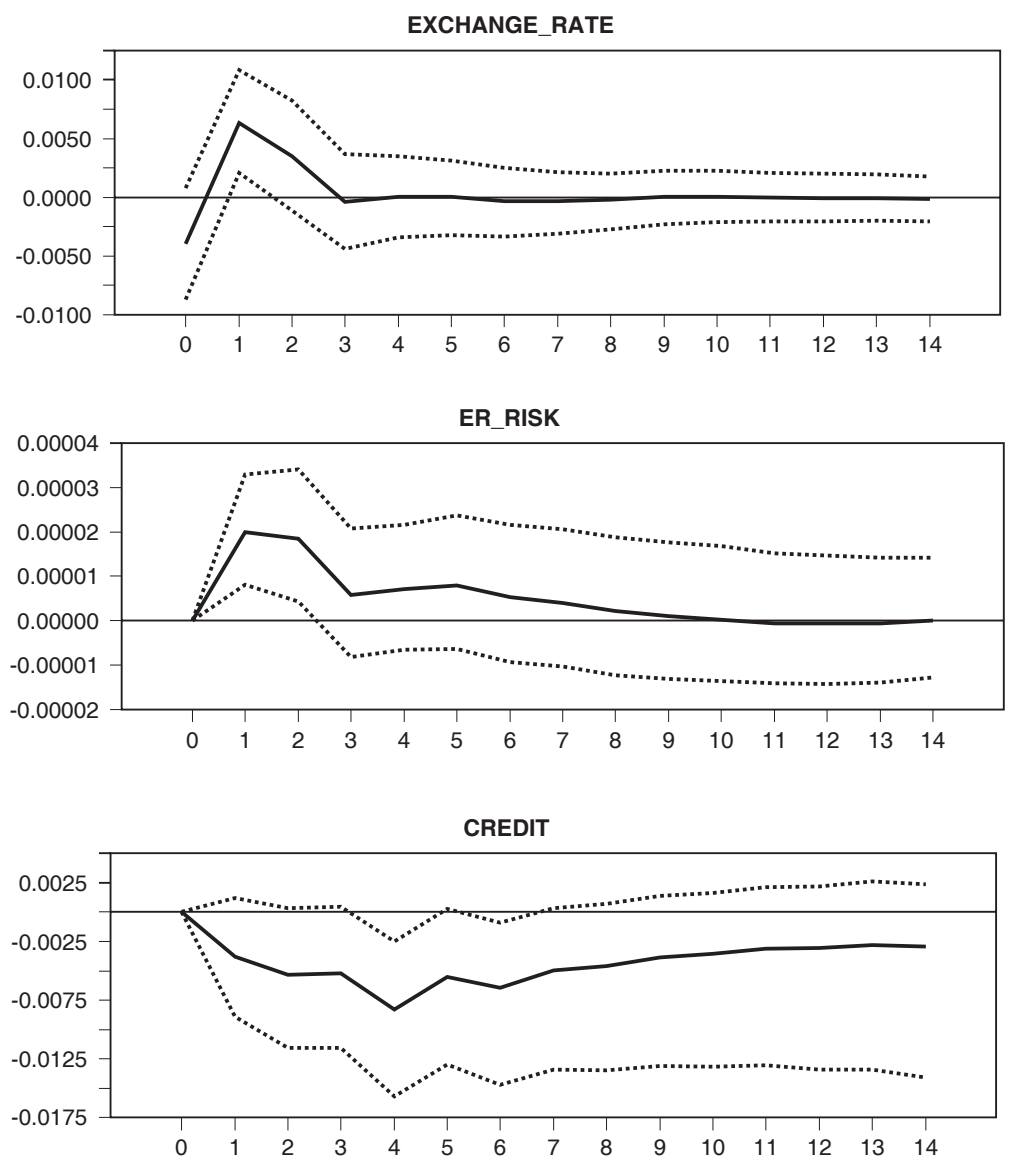

Notes: Significance bands at 5\% level.

\subsection{More detailed effects on consumption and investment}

Here we give some information on the results obtained from VAR3 and VAR4. The output from these models is less robust, which is given by the fact that more variables were used to analyse the possible effects on the selected types of consumption and investment. Also we do not present the output due to the enormous space it would require.

An increase in capital market risk significantly cuts down the consumption of durables. The effects on money market risk and foreign exchange risk remain the same in qualitative terms. Exchange rate risk negatively influences the consumption of both durables and nondurables and also the investment into dwellings. With regard to an overall small negative effect to the output, which was presented in Figure 6, there must be little effect on investment and positive effect on foreign trade. We return to this below. An increase in the money market spread has a slight negative effect on nondurable consumption at $10 \%$ level of significance. 
We divided gross fixed capital formation into investment in buildings and machinery. The impact of an increase in capital market risk is insignificant as far as investments into buildings and machinery are concerned. There are slight negative effects of an increase in the exchange rate risk on the investment into buildings. An increase in the money market risk influence negatively both components of investment and together with the negative effect on consumption adds to a decrease in output. The decrease must be in part compensated by an improvement in foreign balance, which we did not test but it may be explained by the weaker demand (and therefore lower imports). An increase in the money market risk negatively influences investment in both buildings and machinery and together with the negative impact on nondurable consumption in leads to an overall negative effect on output, which was presented in Figure 7.

\section{Conclusions}

The prime goal of this paper was to examine linkages between measures of financial risk, bank credit and real economy. Structural vector autoregressive models were used to capture impulse - response functions for the Czech economy. Three kinds of financial markets' risk were used - capital market risk, foreign exchange risk and money market risk. The capital market risk and foreign exchange risk were estimated with GARCH models and money market risk was captured by the spread between the three-month money market rate and the two-week policy rate of the Czech National Bank.

First an underlying model was examined by running a shock to the external output. The impulse-response functions showed a clear negative impact on domestic output, pro-cyclical development of the money market spread and appreciation of the exchange rate, which are all in line with economic intuition.

Further, the model was enhanced by the two other measures of risk and shocks to the risk variables were performed. The increase in the capital market risk was accompanied by increases in the money market risk and foreign exchange risk pointing to the interactions between the selected segments of the financial market. Higher capital market risk had a direct negative impact on output. The foreign exchange risk did not affect significantly either the money market risk or the capital market risk. Higher volatility of exchange rate influenced negatively the domestic output. The money market risk had the strongest real effects of all the three financial risk measures. The domestic output was heavily negatively affected by an increase in the money market risk. The effect was relatively deep and persistent and accompanied by a lower credit activity. Capital market risk and foreign exchange risk were influenced as well.

Further, we expanded the model by substituting the consumption of durables and investment into dwellings for domestic output in one case and investment into buildings and machinery for domestic output in the second case. We reported the negative effects of financial risk shocks to consumption and investment, which were qualitatively in line with the previous results.

Although the results generally comply with the hypotheses discussed in the theoretical part in qualitative terms, quantitatively the effects of shocks to the variables of financial risk seem to be low. Therefore, we conclude that the shocks to financial risk themselves serve as an amplifying mechanism for real shocks. 


\section{References}

Aarle, B., Garretsen, H., Gobbin, N. (2003), "Monetary and Fiscal Policy Transmission in the Euro Area: Evidence from a Structural VAR Analysis." Journal of Economics and Business, Vol. 55, No. 5-6, pp. 609-638.

Ahtik, M. (2012), “Bank Lending Channel in Slovenia: Panel Data Analysis." Prague Economic Papers, Vol. 21, No. 1, pp. 50-68.

Beneš, J., Ötker-Robe, I., Vávra, D. (2009), “Modeling with Macro-Financial Linkages: Credit and Policy Shocks in Emerging Markets." IMF Working Paper WP/09/123.

Bernanke, B. S., Gertler, M. (1995), "Inside the Black Box: The Credit Channel of Monetary Policy Transmission." Journal of Economic Perspectives, Vol. 9, No. 4, pp. 27-48.

Bernanke, B. S., Blinder, A. S. (1988), "Credit, Money, and Aggregate Demand." American Economic Review, Vol. 78, No. 2, pp. 435-439.

Bernanke, B. S., Gertler, M., Gilchrist, S. (1996), "The Financial Accelerator and the Flight to Quality." Review of Economics and Statistics, Vol. 78, No. 1, pp. 1-15.

Bernanke, B. S., Gertler, M., Gilchrist, S. (1999), "The Financial Accelerator in a Quantitative Business Cycle Framework." In: Taylor JB and Woodford M (eds.) Handbook of Macroeconomics 1C: 1341-1393. Elsevier, $1^{\text {st }}$ ed.

Bijlsma, M., Klomp, J., Duineveld, S. (2010), Systemic Risk in the Financial Sector: A Review and Synthesis, CPB Document 210.

Black F. (1976), "Studies of Stock Price Volatility Changes." American Statistical Association, Proceedings of the 1976 Meetings of the Business and Economics Statistics Section: pp. 177-181.

Brunnermeier, M. K., Pedersen, L. H. (2009), "Market Liquidity and Funding Liquidity." Review of Financial Studies, Vol. 22, No. 6, pp. 2201-2238.

Caballero, R. J. (1991), "On the Sign of the Investment-Uncertainty Relationship." American Economic Review, Vol. 81, No. 1, pp. 279-288.

Caballero, R. J. (1997), "Aggregate Investment." NBER Working Paper Series WP No. 6264.

Caballero, R. J., Krishnamurthy, A. (2003), “Excessive Dollar Debt: Financial Development and Underinsurance." Journal of Finance Vol. 58, No. 2, pp. 867-893.

Chari, V., Kehoe, P. J., McGrattan, E. R. (2007), "Business Cycle Accounting." Econometrica, Vol. 75, No. 3, pp. $781-836$.

Cuthbertson, K., Nitzsche, D. (2005), Quantitative Financial Economics: Stocks, Bonds and Foreign Exchange. Wiley.

Eickmeier, S., Hofmann, B., Worms, A. (2006), "Macroeconomic Fluctuations and Bank Lending: Evidence for Germany and the Euro Area." Deutsche Bank Discussion Paper, Series 1. No. 34/2006.

Fidrmuc J., Horváth R., Horváthová, E. (2010), “Corporate Interest Rates and Financial Accelerator in the Czech Republic." Emerging Markets Finance Trade, Vol. 46, No. 4, pp. 41-54.

Gertler, M., Kiyotaki, N. (2010), "Financial Intermediation and Credit Policy in Business Cycle Analysis." In: Friedman BM and Woodford M (eds.) Handbook of Monetary Economics 3: pp. 547-599. Elsevier, $1^{\text {st }}$ ed.

Ghysels, E., Santa-Clara, P., Valkanov, R. (2005), "There Is a Risk-Return Trade-Off after All." Journal of Financial Economics, Vol. 76, No. 3, pp. 509-548. 
Hamilton, J. D. (1994), Time Series Analysis. Princeton University Press.

Hayashi, F. (1982), "Tobin's Marginal q and Average q: A Neoclassical Interpretation." Econometrica, Vol. 50, No. 1, pp. 213-224.

Heuvel, S. J. den (2006), "The Bank Capital Lending Channel of Monetary Policy." Society for Economic Dynamics Papers No. 512.

Huizinga, J. (1993), "Inflation Uncertainty, Relative Price Uncertainty, and Investment in U.S. Manufacturing." Journal of Money, Credit and Banking, Vol. 25, No. 3, pp. 521-549.

Kiyotaki, N., Moore J. (1997), “Credit Cycles.” Journal of Political Economy, Vol. 105, No. 2, pp. 211-248.

Krishnamurthy, A. (2010), "Amplification Mechanisms in Liquidity Crises." American Economic Journal: Macroeconomics, Vol. 2, No. 3, pp. 1-30.

Ludvigson, S. (1999), “Consumption and Credit: A Model of Time-Varying Liquidity Constraints." Review of Economics and Statistics, Vol. 81, No. 3, pp. 434-447.

Lutkepohl, H. (2005), New Introduction to Multiple Time Series Analysis. Springer.

Matsuyama, K. (2007), "Credit Traps and Credit Cycles." American Economic Review, Vol. 97, No. 1, pp. 503-516.

Moody A., Taylor M. P. (2003), “The High-Yield Spread as a Predictor of Real Economic Activity: Evidence of a Financial Accelerator for the United States." IMF Staff Papers 50: pp. 373-402.

Pellényi, G. (2012), "The Sectoral Effects of Monetary Policy in Hungary: A Structural Factor Analysis." MNB Working Papers 2012/1.

Pindyck, R. S. (1988), "Irreversible Investment, Capacity Choice and the Value of the Firm." American Economic Review, Vol. 78, No. 5, pp. 969-985.

Ryšánek, J., Tonner, J., Vašíček, O. (2011), “Monetary Policy Implications of Financial Frictions in the Czech Republic." Czech National Bank Working Paper No. 12/2011.

Vermeulen P. (2000), "Business Fixed Investment: Evidence of a Financial Accelerator in Europe." ECB Working Paper No. 37. 